\title{
Optimizing a Larger Scale Synthesis of Zyklophin, a Highly Selective Peptide Kappa Opioid Receptor Antagonist
}

\author{
Tatyana V. Yakovleva ${ }^{1,2}$ and Jane V. Aldrich ${ }^{1,2}$ \\ ${ }^{1}$ Department of Medicinal Chemistry, the University of Kansas, Lawrence, KS, 66045, USA; \\ ${ }^{2}$ Department of Medicinal Chemistry, the University of Florida, Gainesville, FL, 32610, USA
}

\section{Introduction}

We are interested in developing metabolically stable peptidic ligands for kappa opioid receptors (KOR) as potential treatments for drug abuse and pain. In particular KOR antagonists have recently demonstrated potential therapeutic applications in the treatment of drug addiction, depression and anxiety [1]. Our research group has designed the KOR antagonist zyklophin ([N-benzylTyr ${ }^{1}$, cyclo-(D- $^{-}$ $\mathrm{Asp}^{5}$,Dap $\left.{ }^{8}\right)$ ]dynorphin A-(1-11) amide, Figure 1) [2] based on the endogenous KOR peptide dynorphin A. Zyklophin is a selective KOR antagonist that exhibits activity in the CNS after peripheral administration [3]. Utilization of this important peptide in vivo requires the synthesis and purification of the peptide on a larger scale, but structural modifications (cyclization and $N$-terminal modification) make its larger scale synthesis and purification more challenging.

Here we describe the optimization of the solid phase synthesis of zyklophin, in particular the

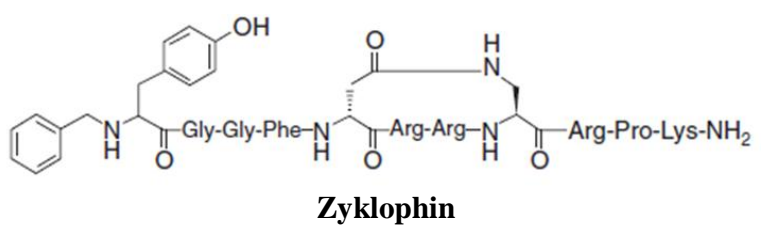

$\mathrm{H}_{2}$-Tyr-Gly-Gly-Phe-Leu-Arg-Arg-Ile-Arg-Pro-Lys-OH Dynorphin A (1-11)

Fig. 1. Structures of zyklophin and dynorphin A (1-11). selective deprotection [4,5] and cyclization of the side chains of D-Asp ${ }^{5}$ and Dap $^{8}$ (2,3-diaminopropionic acid), and the use of microwave irradiation to facilitate the rapid cyclization of the side chains. To substantially increase the amount of peptide purified per chromatographic run we utilized a modified reversed phase HPLC purification method [6]. These modified procedures permitted preparation of the larger quantities of pure peptide ( $>200 \mathrm{mg}$ ) necessary for extensive studies in vivo.

\section{Results and Discussion}

Zyklophin was synthesized by a combination of solid phase peptide synthesis (SPPS) of the (2-11) fragment followed by coupling of the $N$-terminal N-benzyl-Tyr-OH. SPPS of zyklophin (2-11) was performed at room temperature or by microwave irradiation using the Fmoc synthetic strategy on the low load $(0.18 \mathrm{mmol} / \mathrm{g})$ Fmoc-PAL-PEG-PS resin. The peptide was assembled through D-Asp ${ }^{5}$, then cyclized, followed by further extension of the peptide chain to give $\left.c y c l o\left(\mathrm{D}-\mathrm{Asp}^{5}, \mathrm{Dap}^{8}\right)\right] \mathrm{Dyn} \mathrm{A}(2-11)-\mathrm{NH}_{2}$.

The synthesis conditions were optimized for a $1 \mathrm{mmol}$ scale synthesis of zyklophin (Table 1). The time for selective deprotection of the 2-phenylisopropyl (OPip) and N-methyltrityl (Mtt) protecting groups with $3 \%$ TFA was increased by 2 -fold since it appeared that the deprotection, possibly of the OPip group, required longer time in the larger scale syntheses. Prolonging the selective deprotection of the side chains of Dap(Mtt) and D-Asp(OPip) allowed the cyclization step to go to completion at room temperature overnight, thereby improving the overall yield of pure zyklophin.

Table 1. Comparison of small and larger scale zyklophin syntheses.

\begin{tabular}{ccc}
\hline & Small scale & Larger scale \\
\hline Resin used & $36-90 \mu \mathrm{mol}$ & $900 \mu \mathrm{mol}(5 \mathrm{~g})$ \\
& $(0.2-0.5 \mathrm{~g})$ & $1175 \mathrm{mg}$ \\
Yield crude peptide & $49-124 \mathrm{mg}$ & $78-82 \%$ \\
Crude peptide purity & $68-72 \%$ & \\
\hline
\end{tabular}

To facilitate the synthesis microwave irradiation (Biotage Initiator+ Alstra) was also investigated. A $180 \mu \mathrm{mol}$ scale synthesis of zyklophin (2-11) was performed successfully using microwave irradiation on the PAL-PEG-PS resin, and the crude peptide was obtained in high purity (78-82\%). Figure 2 shows that the cyclization 

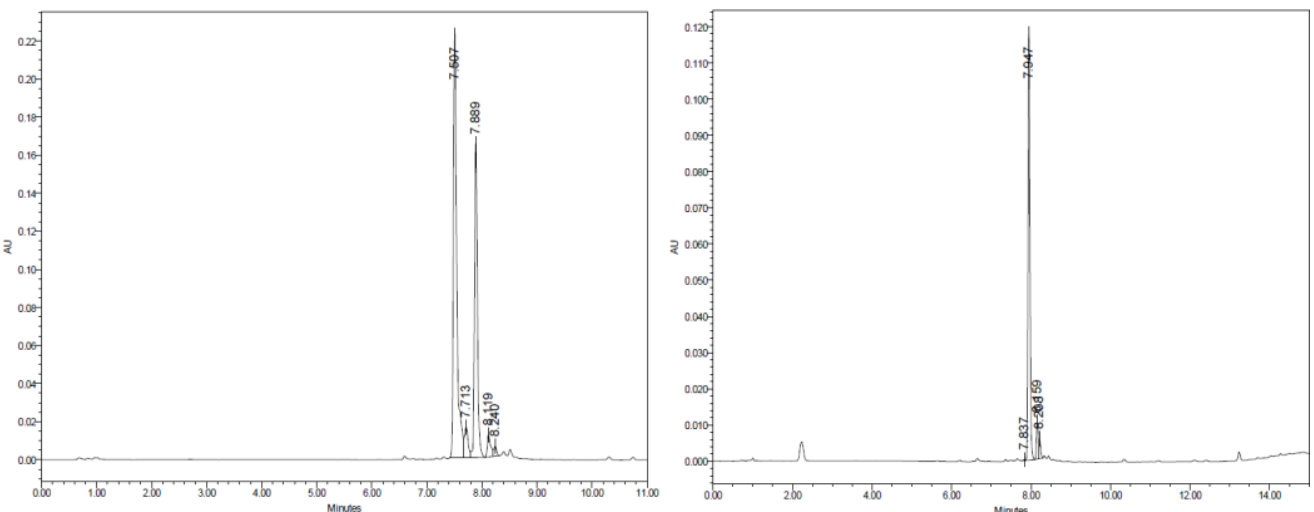

Fig. 2. Microwave-assisted cyclization of zyklophin 5-11, a) Cyclization for 5 min at $75^{\circ} \mathrm{C}$, $46 \%$ cyclization $\left(t_{R}=7.51 \mathrm{~min}\right.$, linear; $t_{R}=7.89 \mathrm{~min}$, cyclic peptide; b) Cyclization $2 \times 5$ min at $75^{\circ} \mathrm{C}$, $>99 \%$ cyclization $\left(t_{R}=7.94 \mathrm{~min}\right)$.

reaction with PyClock, HOAt, and DIEA in DMF went to completion after 2 x 5 min microwave irradiation at $75^{\circ} \mathrm{C}$, compared to overnight at r.t.

Purification was performed by reversed phase HPLC. A modified method [6] with a slow gradient and high TFA concentration was used that substantially increased the amount of purified peptide obtained per chromatogram run compared to the standard method, permitting preparation of the larger quantities of pure peptide needed for its extensive evaluation in vivo, and decreasing expenses related to larger columns and larger volumes of solvent consumption. This method allowed purification of $220 \mathrm{mg}$ of zyklophin in a single chromatographic run, compared to loading of 20-25 mg crude peptide per run using the standard method (Table 2 ), with similar overall purity $(>97.5 \%)$.

$\mathrm{N}-\mathrm{Benzyl}-\mathrm{Tyr}-\mathrm{OH}$ was prepared in solution by reductive amination [2] of Tyr-O $t \mathrm{Bu}$ followed by TFA deprotection of the $t$-butyl ester. This amino acid was then coupled to zyklophin (2-11) using PyClock, HOAt and DIEA in DMF. Dissolution of N-benzyl-Tyr-OH in DMF required warming to $80-85^{\circ} \mathrm{C}$, then cooling to $25-30^{\circ} \mathrm{C}$ prior to adding the coupling reagents and addition of the mixture to zyklophin (2-11) to prevent possible racemization. The zyklophin derivative with N-benzyl-D-Tyr ${ }^{1}$ was also synthesized and used as an HPLC standard to verify that racemization of the $N$-terminal residue did not occur during the final coupling.

Table 2. Comparison of small and larger scale zyklophin purifications.

\begin{tabular}{ccc}
\hline & $\begin{array}{c}\text { Small scale/ } \\
\text { Standard purification }\end{array}$ & $\begin{array}{c}\text { Larger scale/ }^{a} \\
\text { Modified purification }^{b}\end{array}$ \\
\hline $\begin{array}{c}\text { Amount purified/injection } \\
\text { Total crude peptide } \\
\text { (\# chromatograph runs) } \\
\text { Yield pure peptide/injection, } \\
(\% \text { recovery) }\end{array}$ & $20-25 \mathrm{mg}$ & $55-220 \mathrm{mg}$ \\
Total pure peptide & $150 \mathrm{mg}(7)$ & $676 \mathrm{mg}(7)$ \\
Amount of solvent used & $37 \mathrm{mg}(28 \%)$ & $12-42 \mathrm{mg}(19-29 \%)$ \\
\hline
\end{tabular}

${ }^{a}$ Vydac C18 column $(22 \times 250 \mathrm{~mm}, 300$ Á pore size, $10 \mu \mathrm{m})$, equipped with a Vydac guard cartridge; 5-30\% aq. MeCN/O.1\% TFA over 50 min.; ${ }^{b}$ Zorbax SB-C18 column $(9.4 \times 250 \mathrm{~mm}$, 300 Á pore size, $5 \mu \mathrm{m})$, equipped with a Zorbax guard cartridge; $5-30 \%$ aq. MeCN/0.2\% TFA over $250 \mathrm{~min}$. 
The larger scale synthesis and purification of zyklophin were optimized by utilizing microwave irradiation and a modified HPLC purification protocol, respectively. Microwave irradiation facilitated the cyclization, decreasing the reaction time from overnight to $10 \mathrm{~min}$ with comparable yields and purity of the final peptide. Utilizing a modified HPLC protocol allowed purification of a 10-fold larger amount of zyklophin on a smaller diameter column compared to our standard method. These optimized synthesis and purification conditions should be applicable to a variety of cyclic peptides, facilitating their in vivo pharmacological evaluation where larger quantities are required.

\section{Acknowledgments}

Research supported by grant R01 DA023924 (National Institute on Drug Abuse).

\section{References}

1. Aldrich, J.V., McLaughlin, J.P. AAPS J. 11, 312-322 (2009), http://dx.doi.org/10.1208/s12248-009-9105-4

2. Patkar, K., et al. J. Med. Chem. 48, 4500-4503 (2005), http://dx.doi.org/10.1021/jm050105i

3. Aldrich, J.V., et al. Proc. Natl. Acad. Sci. USA 106, 18396-18401 (2009), http://dx.doi.org/10.1073/pnas.0910180106

4. Li, D., Elbert, D.L. J. Peptide Res. 60, 300-303 (2002), http://dx.doi.org/10.1034/j.1399-3011.2002.21018.x

5. Yue, C., et al. Tetrahedron Lett. 34, 323-326 (1993), http://dx.doi.org/10.1016/S0040-4039(00)60578-6

6. Chen, Y., et al. J. Chromatogr. A 1140, 112-120 (2007), http://dx.doi.org/10.1016/j.chroma.2006.11.052 